\title{
SIMULTANEOUS ESTIMATION OF ISONIAZID AND PYRIDOXINE HYDROCHLORIDE IN TABLET DOSAGE FORM BY SPECTROPHOTOMETRY ULTRAVIOLET WITH AREA UNDER CURVE METHOD
}

\author{
LISDA RIMAYANI NASUTION*, MUCHLISYAM BACHRI, EFFENDY DE LUX PUTRA \\ Department of Pharmaceutical Chemistry, Faculty of Pharmacy, Universitas Sumatera Utara, Medan, Indonesia. \\ Email: Muchlisyam@usu.ac.id
}

Received: 16 December 2017, Revised and Accepted: 22 January 2018

ABSTRACT

Objective: This study aimed to develop spectrophotometry ultraviolet (UV) method by area under curve (AUC) to determine the levels of isoniazid (INH) and pyridoxine hydrochloride (PDX) in commercial tablets.

Methods: Spectrophotometry UV method by AUC tested is carried out by optimizing the type of solvent, methanol, mixture of methanol, and phosphate buffer $\mathrm{pH} 4, \mathrm{pH}$, and $\mathrm{pH} 6$ at a ratio of 90:10. The AUC value of each spectrum in various concentrations is calculated to selected wavelength range analysis. Then, this method was applied to determine the levels of INH and PDX in commercial tablets.

Results: The application of AUC spectrophotometry UV method for determining the levels of INH and PDX was performed on wavelength range 262.2-272.2 $\mathrm{nm}$ and $289.8-299.8 \mathrm{~nm}$, respectively. The selection of wavelengths based on wavelengths gives the best result. The mean \% recoveries were found to be at $99.69 \%$ and $101.09 \%$ for INH and PDX, respectively.

Conclusion: The method is successfully applied to analyze INH and PDX in pharmaceutical formulation simultaneously with no interference from excipients as indicated by all validation parameters which were within the acceptable range.

Keywords: Isoniazid, Pyridoxine hydrochloride, Area under curve, Spectrophotometry ultraviolet.

(c) 2018 The Authors. Published by Innovare Academic Sciences Pvt Ltd. This is an open access article under the CC BY license (http://creativecommons. org/licenses/by/4. 0/) DOI: http://dx.doi.org/10.22159/ajpcr.2018.v11i5.24314

\section{INTRODUCTION}

Isoniazid (INH) was introduced in 1952 as a drug that is quite effective in the treatment of tuberculosis [1]. Its chemical name is pyridine-4carbohydrazide [2]. It was soluble in water, rather difficult to dissolve in ethanol, difficult to dissolve in chloroform and ether. Based on the germicidal properties of its tuberculosis, to obtain the effectiveness of treatment and prevent the emergence of resistance, one of the principles used is to prioritize the drug combinations [3]. One such combination is a INH and pyridoxine hydrochloride (PDX) [3].

The chemical name of PDX is 5-hydroxy-6-methyl-3,4pyridine-dimethanol hydrochloride [2]. It is also called as Vitamin B6 [2]. It was freely soluble in water, soluble in methanol, and not soluble in ether [1]. It was given to the patients taking INH to prevent peripheral neuropathy and central nervous system effects that are associated with the use of INH [3].

Some analytical methods have been developed for the quantitative analysis of INH or PDX in pure individual drugs, in their combination, in the pharmaceutical dosage forms, and in the biological fluids. These methods are Fourier transform infrared [4], voltammetric assay [5,6], spectrophotometry ultraviolet (UV) [7-15], polarography [12] and chemiluminescence [13], reverse phase (RP)-liquid chromatography (LC) [14], RP-high-performance LC [15], and high-performance thin LC [16].

Spectrophotometry UV with an area under curve (AUC) method for simultaneous estimation is a simple, accurate, and precise with no interference from excipients. It is no required long time to sample preparation, no many solvents, no complicated mathematical equations and no derivatization processes for finding the zero crossing value [17]. According to the best of our knowledge, there is no published spectrophotometry UV with AUC method for simultaneous estimation INH and PDX in their combination.

\section{METHODS}

Reagents and chemicals

All material and reagents were analytical reagent grade. The raw standard of INH was purchased from Zhejiang Jiangbei Pharmaceutical Industry, and the raw standard PDX was purchased from Jiangxi Tianxin Pharmaceutical Industry. Commercially available tablets Pehadoxin Forte ${ }^{\circledR}$ (containing $400 \mathrm{mg}$ INH and $10 \mathrm{mg}$ PDX, Phapros, Indonesia) and tablets TB Vit $6^{\circledR}$ (containing $400 \mathrm{mg}$ INH and $25 \mathrm{mg}$ PDX, Meprofarm, Indonesia) were obtained from a local pharmacy.

\section{Instruments and apparatus}

The spectrophotometric measurements were carried out on a Shimadzu-UV 1800 Spectrophotometer, matched quartz cells $1 \mathrm{~cm}$, and UV probe 2.42 software was used for all spectral measurements. Boeco analytical balance, Branson 1510 Ultrasonicator, and Hanna pH meter were also used.

\section{Optimizing of Solvent}

Optimizing of solvent is performed by measuring the absorbance of INH and Vitamin B6 in methanol, a mixture of methanol, and phosphate buffer $\mathrm{pH} 4, \mathrm{pH}$ 5, and $\mathrm{pH} 6$ in the ratio (90:10) at the wavelength range of 200-400 nm. It was observed that the solutions in methanol showed suitable conditions for the simultaneous estimation of both drugs. Methanol was selected as the solvent for further study.

\section{Preparation of standard solution}

Accurately weighed $50 \mathrm{mg}$ of INH and PDX standard was separately transferred into $50 \mathrm{ml}$ volumetric flask and dissolved in methanol to give solutions containing $1000 \mu \mathrm{g} / \mathrm{ml}$ INH and PDX. 
Selection of analytical wavelength

The solutions of INH and PDX were prepared in diluent by appropriate dilution and the spectrum was recorded. The absorption spectra of the solutions prepared at different concentrations of INH $(5-15 \mu \mathrm{g} / \mathrm{ml})$ and PDX $(6-18 \mu \mathrm{g} / \mathrm{ml})$ were scanned in the range $200-400 \mathrm{~nm}$. The AUC value of each spectrum in various concentrations is calculated to get the analytical wavelength.

Assay of tablet formulation by AUC spectrophotometry UV method The content of twenty tablets was weighed accurately. A powder quantity equivalent to $69.1 \mathrm{mg}$ INH and $3.21 \mathrm{mg}$ PDX was accurately weighed and transferred to the volumetric flask of $50 \mathrm{ml}$. Then, $15 \mathrm{ml}$ of methanol was transferred to this volumetric flask and sonicated for $15 \mathrm{~min}$. The flask was shaken and volume was made up to the mark with diluent. The above solution was filtered through Whatman filter paper $(0.45 \mu)$. The solution was made up to the mark with diluent to give a solution containing $12 \mu \mathrm{g} / \mathrm{ml}$ of INH and $12 \mu \mathrm{g} / \mathrm{ml}$ of PDX (by addition PDX standard solution). The resulting solution was analyzed by the proposed method. The quantification analysis was carried out by keeping these values to the straight line equation of calibration curve.

\section{Method validation}

The method was validated based on linearity, accuracy, precision, limit of detection (LOD), and limit of quantification (LOQ). It was validated according to the International Conference on Harmonization guidelines.

\section{RESULT AND DISCUSSION}

\section{Selection of analytical wavelength}

Selection of analytical wavelength is carried out by calculating the AUC value of each spectrum in various concentrations at the wavelength range 255-275 $\mathrm{nm}$ for INH and the 281-295 nm wavelength range for PDX. The selected wavelength range is the best linear relation between its AUC value and its concentration that indicated by the correlation coefficient value (value $r$ is $\leq 1$ ) closed to one [18].

The selected wavelengths to determine INH and Vitamin B6 by spectrophotometry UV with AUC method were 262.2-272.2 nm and 289.8-299.8 nm, respectively (Fig. 1).

Based on Fig. 1, we can conclude that no overlapping AUC of each wavelength ranges both for INH (262.2-272.2 nm) and PDX (289.8$299.8 \mathrm{~nm}$ ) and affecting one to another. According to this result, the spectrophotometry UV with AUC method can be used to simultaneously determine the drug content consisting of more than one component [19].

\section{Method validation}

The low values of percent relative standard deviation are indicative of the precision and reproducibility of the method. The resulting mixtures were assayed according to the above-stated procedure, and the results were calculated as the percentage of analyst recovered. LOD and LOQ values were indicated that the method shows high sensitivity. The good recovery values assure the high accuracy of the proposed method. Validation parameters for this method are shown in Table 1.

Some studies have been reported about spectrophotometry by AUC method and gave good validation method result $[20,21]$. Based on Table 1 , this research has good validation method result for simultaneous INH and PDX in their combined tablet dosage form.

\section{Application of the method in commercial tablet}

The proposed method was applied for the determination of INH and PDX in their combined commercial tablet, and the result are shown in Table 2.

The results of analysis of pharmaceutical dosage form by the proposed method are in good agreement with a label claim of the drug. However, some studies have been reported [11], and according to this result, the proposed method is potential to use in routine drug analysis, especially

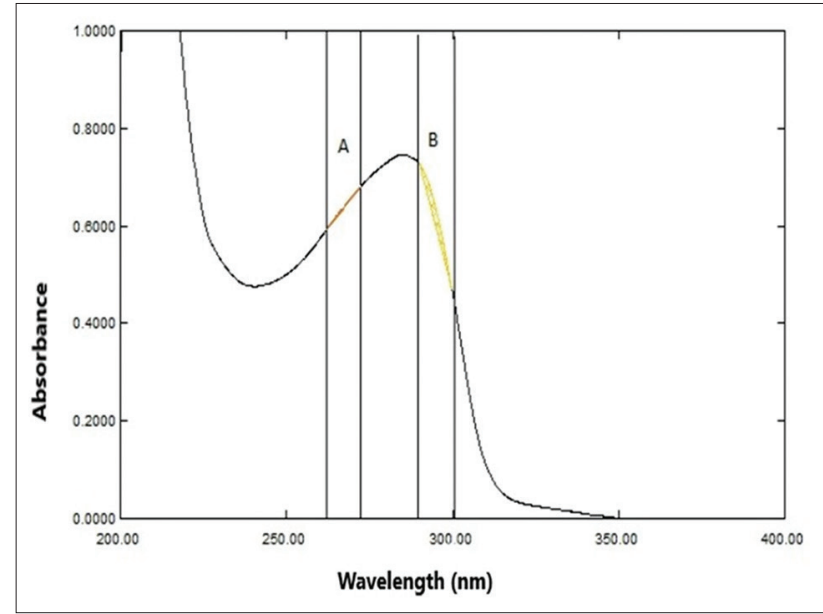

Fig. 1: Analytical wavelength range selected for isoniazid (INH) and pyridoxine hydrochloride (PDX). (a) Analytical wavelength range selected for INH (262.2-272.2 nm), (b) analytical wavelength range selected for PDX (289.8-299.8 nm)

Table 1: Validation parameters for INH and PDX

\begin{tabular}{lll}
\hline Parameters & INH & PDX \\
\hline Linearity & 0.09979 & 0.9989 \\
Accuracy (\%) & 99.69 & 101.09 \\
Precision (RSD) (\%) & 1.17 & 0.73 \\
LOD & 0.0033 & 0.0312 \\
LOQ & 0.0110 & 0.1040 \\
\hline
\end{tabular}

PDX: Pyridoxine hydrochloride, INH: Isoniazid, RSD: Relative standard deviation, LOD: Limit of detection, LOQ: Limit of quantification

Table 2: Result of quantification of INH and PDX in commercial tablet

\begin{tabular}{llll}
\hline $\begin{array}{l}\text { Commercial } \\
\text { tablet }\end{array}$ & $\begin{array}{l}\text { Drugs } \\
\text { content }\end{array}$ & $\begin{array}{l}\text { Amount found } \\
\text { (mg/tablet) }\end{array}$ & $\begin{array}{l}\text { Label claim } \\
\text { (mg/tablet) }\end{array}$ \\
\hline Tablet P & INH & $398.04 \pm 0.06$ & 400 \\
& PDX & $9.94 \pm 0.59$ & 10 \\
Tablet T & INH & $397.48 \pm 0.18$ & 400 \\
& PDX & $25.25 \pm 0.49$ & 25 \\
\hline
\end{tabular}

PDX: Pyridoxine hydrochloride, INH: Isoniazid

drugs with contained the combination of several drugs. It is easy to work, especially for routine analysis and not require long conditioning tools.

\section{CONCLUSION}

The proposed method provides a simple, accurate, and precise quantitative analysis for the estimation of INH and PDX as a binary mixture. The proposed method is simple as there is no need for solvent extraction and direct as it estimates each component independent of the other and also low cost and harmless to the environment. Hence, it could be applied in the routine simultaneous analysis in quality control laboratories.

\section{ACKNOWLEDGMENTS}

The authors gratefully acknowledge all the parties involved in this research, especially to all staff of Research Laboratory Universitas Sumatera Utara and all staff of Department Pharmaceutical Chemistry Universitas Sumatera Utara.

\section{CONFLICT OF INTEREST}

We declare that there is no conflict of interest. 


\section{REFERENCES}

1. Tjay TH, Kirana R. Medicines Important Usefulness, Use and Side Effects. $6^{\text {th }}$ ed. Jakarta: Elex Komputindo; 2007. p. 159.

2. Depkes RI. Indonesian Pharmacopeia. $4^{\text {th }}$ ed. Jakarta: Department of Healthy Indonesian; 1995. p. 254, 649, 1067.

3. Prawinata H, Sugiastana BN, Wijaya K, Dharmapradnyawati NP, Widhiartini A, GelgelA, Widjaja P, Kadjeng N. Development of the HPTLC Method Spectrophotometricometry for Separation of Rifampicin, INH, Pirazinamid and Etambutol Compounds. J Kefarmasian 2013;1:1-3.

4. Nugrahani I, Citra K. Determination of thiamine $\mathrm{HCl}$ (Vitamin B1) and pyridoxine $\mathrm{HCl}$ (Vitamin B6) content in tablet by FTIR. Int J Pharm Pharm Sci 2016;8:257-64.

5. Hammam E, Belthagi AM, Ghoneim, MM. Voltammetric assay of rifampicin and isoniazid drugs, separately and combined in bulk, pharmaceutical formulations and human serum at a carbon paste electrode. Microchem J 2004;77:53-62.

6. Cottica SM, Jorge N, Helena SN, Claudio CO, Nilson ES, Jesui VV. Voltammetric determination of Pyridoxine (vitamin B6) in drugs using a glassy carbon electrode modified with Chromium (III) hexacyanoferrate (II). J Braz Chem Soc 2009;20:496-501.

7. Consigliere VO, Nelson RF, Joao FM. First derivative spectrophotometric determination of pyridoxine in pharmaceutical preparations. Anal Lett 2001;34:1875-88.

8. Enoche FO. Spectrophotometric determination of isoniazid in pure and phahrmaceutical formulations using vanillin. Int J Pharm Pharm Sci 2010;2:55-8.

9. Hegazy MA, Nada SA, Ahmed SF. A novel spectral resolution and simultaneous determination of multicomponent mixture of Vitamin B1, B6, B12, benfotiamine and diclofenac in tablets and capsules by derivatif and MCR-ALS. Spectrochim Acta A Mol Biomol Spectroscopy 2015;140:524-33.

10. Manal SK, Barsoum NB, Mohammed DM. Spectrophotometric determination of isoniazid and rifampicin from pharmaceutical preparations and biological fluids. Res J Agric Biol Sci 2008;4:471-84.

11. Pratap YP, Anjali VL, Sandhya NB, Sumedha RR, Rathi R. Simultaneous
UV spectrophotometric method for estimation isoniazid and pyridoxine in tablet dossage form. Pharm Chem Lett 2012;5:749-54.

12. Asadpour Z, Payam SA. Simultaneous polarographic determination of Isoniazid and Rifampicin by differential pulse polarographic method and support vector regression. Electrochim Acta 2010;55:6570-6.

13. Li B, He Y, Lv J, Zhang Z. Simultaneous determination of rifampicin and isoniazid by continuous-flow chemiluminescence with artificial neural network calibration. Anal Bioanal Chem 2005;383:817-24.

14. Calleri E, De Lorenzi E, Furlanetto S, Massolini G, Caccialanza G. Validation of a RP-LC method for the simultaneous determination of isoniazid, pyrazinamide and rifampicin in a pharmaceutical formulation. J Pharm Biomed Anal 2002;29:1089-96.

15. Umang S, Jasani A. UV Spectrophotometric and RP-HPLC methods for simultaneous estimation of isoniazid, rifampicin and piperine in pharmaceutical dosage form. Int J Pharm Pharm Sci 2014;6:274-80.

16. Puthusseri S, Matthew M. Validated HPTLC method for simultanestimation of rifampicin, INH and pyridoxine hydrochloride in combined tablet dossage form. Int J Pharm Res 2014;3:523-36.

17. Chaudhary J, Jain A, dan Saini V. Simultaneous estimation of multicomponent formulations UV-visible spectroscopy: An overview. Int Res J Pharm 2011;2:81-3.

18. Sangeetha S, Kumar M, Kumudhavalli MV, Alexander S, Jaykar B. Development and validation of UV spectrophotometric area under curve method for quantitative estimation of piperacilin and tazobactam. Int J Chemtech Res 2017;1:988-94.

19. Mali AD. Estimation of ranitidine in bulk and formulation by second order derivative area under curve UV-Spectrophotometric methods. Int J Anal Pharm Biomed Sci 2015;4:7-16.

20. Sakhare RS, Sanjay SP, Tukaram VG. Development and validation of stability indicating area under curve method for simultaneous estimation of ambroxol hydrochloride and loratadine in bulk and tablet dosage form. Pharm Lett 2016;8:208-15.

21. Rana S, Jigar P, Sagar S, Mandev P. Development and validation of spectrophotometric method for simultaneous estimation of lafutidine and domperidone in combined dosage form by area under curve method. Int J Drug Dev Res 2012;1:257-62. 